\title{
Analisa Perlambatan Kecepatan Kendaraan Di Penghujung Traffic Light Perempatan Jalan Dengan Menggunakan Persamaan Differensial Derajad Satu. (Studi Kasus Ruas Jalan Ir. H. Soekarno-Kertajaya Indah Surabaya)
}

\author{
Hendrata Wibisana ${ }^{1, *}$, Nugroho Utomo ${ }^{1}$, Decynthia Wibowo ${ }^{1}$ \\ Program Studi Teknik Sipil, UPN Veteran Jawa Timur ${ }^{1}$ \\ Koresponden*, Email: hendrata2008@ gmail.com
}

\begin{tabular}{ll}
\hline \multicolumn{1}{c}{ Info Artikel } & Abstract \\
\hline Diajukan 7 Nopember 2017 & $\begin{array}{l}\text { One of the parameters used to monitor the characteristics of the highway is the speed of the } \\
\text { vehicle. Vehicle speed factor plays an important role in the description of the dynamics of traffic } \\
\text { Diperbaiki } 6 \text { Desember } 2017\end{array}$ \\
$\begin{array}{l}\text { flow of a highway, where with high vehicle speed can be predicted high traffic flow on the road. } \\
\text { The aims of the research is to find a model equation that can describe the speed of the vehicle } \\
\text { at one time in the selected arterial road such as the road Ir. H. Soekarno which has a high } \\
\text { volume of vehicles. The resulting equation model can be utilized for vehicle analysis at stopping } \\
\text { point at the zebra cross or intersection with traffic light. The method used in this study based on } \\
\text { vehicle speed data input and applied to the calculation with differential equations of degree } 1\end{array}$ \\
$\begin{array}{l}\text { and obtained a form of mathematical model. The mathematical equations obtained from this } \\
\text { research on segment of the Ir. H. Soekarno road are St }=50,92 . e \wedge(-0.0684 . t) \text { where St is the } \\
\text { vehicle speed in } \mathrm{km} / \mathrm{h} \text { and t is the travel time in hours. }\end{array}$
\end{tabular}

\begin{abstract}
Abstrak
Salah satu parameter yang digunakan untuk memantau karakteristik dari ruas jalan raya adalah kecepatan kendaraan. Faktor kecepatan kendaraan memainkan peranan yang penting dalam penggambaran dinamika arus lalu lintas suatu jalan raya, dimana dengan kecepatan kendaraan yang tinggi dapat diprediksikan arus lalu lintas yang tinggi pada ruas jalan tersebut. Dalam penelitian ini hendak dicari suatu model persamaan yang dapat menggambarkan kecepatan kendaraan pada suatu saat di ruas jalan arteri terpilih yaitu jalan Ir. H. Soekarno yang memiliki volume kendaraan yang tinggi. Model persamaan yang dihasilkan akan dapat dimanfaatkan untuk analisa kendaraan pada titik perhentian di pertigaan atau perempatan dengan adanya traffic light. Metode yang digunakan dalam penelitian ini berdasarkan masukan data kecepatan kendaraan dan diaplikasikan pada perhitungan dengan persamaan differensial derajad 1 dan diperoleh suatu bentuk model matematis. Persamaan matematis yang diperoleh dari penelitian di ruas jalan Ir. $H$.

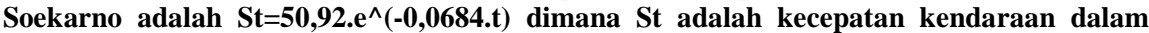
satuan $\mathrm{km} / \mathrm{jam}$ dan $\mathrm{t}$ adalah waktu tempuh dalam satuan jam.
\end{abstract}

Kata kunci: kecepatan kendaraan, analisa perlambatan, traffic light, persamaan differensial

\section{Pendahuluan}

Sebuah kendaraan bermotor apabila melintas di jalan raya akan memiliki kecepatan yang tidak konstan, hal ini disebabkan karena dinamika yang terjadi pada ruas jalan raya tersebut, banyak faktor yang mengakibatkan pengurangan kecepatan kendaraan agar terhindar dari kecelakaan [1]-[4]. Sebagai sebuah jalan yang memiliki volume kendaraan yang tinggi dengan luas penampang lintang jalan yang besar akan memungkinkan pergerakan kendaraan yang bersifat dinamis. Dalam usaha untuk menyajikan ruas jalan yang dapat dipergunakan dengan baik dan tepat guna oleh masyarakat transportasi harus ditunjang dengan management transportasi jalan yang baik dan benar [5], [6].

Kota Surabaya sebagai salah satu kota metropolitan memiliki banyak ruas jalan arteri yang bervolume kendaraan tinggi, seiring dengan adanya tingkat perekonomian yang tinggi serta pendapatan perkapita masyarakatnya yang cukup besar maka dinamika pergerakan kendaraan di berbagai ruas jalan di kota Surabaya cukup bervariasi[7], [8]. Salah satu ruas jalan arteri yang memiliki volume lalu lintas yang tinggi adalah ruas jalan Ir. H. Soerkarno yang menghubungkan surabaya utara dengan surabaya selatan dan disebut sebagai Middle east ring road (MERR), sehingga jalan ini merupakan urat nadi jalan yang terletak pada bagian timur kota surabaya seperti terlihat pada gambar 2 .

Kecepatan kendaraan merupakan salah satu parameter yang sering dipakai untuk menganalisa karakteristik dari sebuah jalan yang memiliki volume lalu lintas yang tinggi, dimana dengan volume lalu lintas tinggi rawan adanya kemacetan [9], [10] dan terjadinya tabrakan antar kendaraan 
bermotor [11]-[13]. Sebuah kendaraan pada saat volume lalu lintas rendah dapat melaju dengan kecepatan melebihi dari kecepatan yang dipersyaratkan untuk ruas jalan tersebut, namun pada saat volume lalu lintas yang tinggi sebuah kendaraan akan bergerak melambat, dipercepat, melambat lagi seiring dengan dinamika pergerakan total kendaraan yang ada pada ruas jalan tersebut.

Untuk dapat dinyatakan dalam model matematika yang dapat menggambarkan secara empiris pergerakan kendaraan, kecepatan kendaraan bergerak sebagai fungsi dari waktu dan akan memiliki perlambatan sebagai bentuk -k.S, dimana $S$ adalah notasi dari kecepatan kendaraan dan k adalah koefisien pergerakan kendaraan, tanda negatip menyatakan bentuk perlambatan. Rumusan tersebut dapat dinyatakan dalam bentuk persamaan differensial sebagai berikut :

$\frac{d S}{d t}=-k * S$

Dengan memindah parameter $\mathrm{S}$ diperoleh bentuk persamaan

$\frac{d S}{S}=-k * d t$

$\frac{\mathrm{dS}}{\mathrm{S}}=-\mathrm{k} * \mathrm{dt}$

Persamaan 3 merupakan bentuk integral dari rumusan perlambatan kendaraan, dan apabila dilakukan pengintegralan pada persamaan 3 , dan menjadikannya bentuk persamaan eksponen akan diperoleh hasil

$\ln \mathrm{S}_{\mathrm{t}}-\mathrm{S}_{0}=-\mathrm{k} \cdot \mathrm{t}+\mathrm{C}$

$S_{t}-S_{0}=e^{-k \cdot t+C}$

$S_{t}-S_{0}=e^{-k \cdot t} \cdot C$

$S_{t}=S_{0}+C \cdot e^{-k \cdot t}$

Persamaan 7 merupakan bentuk umum dari model persamaan differensial derajad 1 untuk pergerakan kendaraan pada sebuah jalan raya, dimana:

$\mathrm{S}_{\mathrm{t}}=$ kecepatan kendaraan pada saat $\mathrm{t}$ (dalam satuan $\mathrm{km} / \mathrm{jam}$ )

$\mathrm{S}_{0}=$ kecepatan kendaraan saat berhenti

$\mathrm{C}=$ konstanta empiris

$\mathrm{t}=$ waktu pergerakan kendaraan (detik)

$\mathrm{k}=$ konstanta pergerakan kendaraan

Penelitian ini bertujuan untuk mendapatkan model persamaan differensial derajad 1 yang dapat menggambarkan pergerakan kendaraan saat mengalami perlambatan akibat lampu merah dari traffic light, dimana pada saat lampu merah pada jarak tertentu sebuah kendaraan akan melakukan gerakan melambat hingga mencapai garis marka zebra cross, disamping itu akan dianalisis juga berapakah waktu yang dibutuhkan oleh sebuah kendaraan untuk berhenti tepat pada garis zebra cross dari traffic light.

\section{Bahan dan Metode}

Bahan yang dibutuhkan dalam penelitian ini adalah alat pengukur kecepatan kendaraan atau stopwatch dengan beberapa bendera kecil yang ditancapkan pada batas yang sudah ditandai dengan diberi jarak 50 meter untuk segmen 1 dan 50 meter untuk segmen 2. Untuk pemberian tanda batas ini dilakukan dari batas tepi zebra cross ke arah belakang dari ruas jalan 50 meter sebagai segmen 2 dan untuk segmen 1 dilakukan dengan menghubungkan batas segmen 2 seperti terlihat pada gambar 1 .

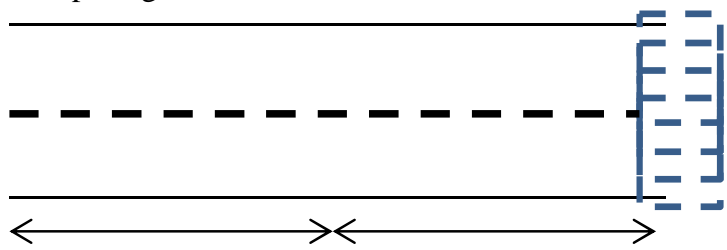

Gambar 1. Penampang lintang jalan dibagi dalam 2 segmen sepanjang 50 meter

Pengukuran dilakukan dengan menempatkan 2 orang surveyor pada masing-masing segmen dimana kecepatan kendaraan dicatat tiap 15 menit berjalan selama 3 jam pengamatan sehingga nantinya diperoleh 12 data kecepatan kendaraan bermotor yang dikonversi dari meter/detik menjadi $\mathrm{km} / \mathrm{jam}$. Untuk pencatatan dilakukan terhadap 1 jenis kendaraan yang melintas pada segmen 1 untuk mendapatkan nilai kecepatan awal dengan cara menekan stopwatch pada saat roda depan kendaraan sudah melewati batas bendera yang sudah ditetapkan sebelumnya, dan pada saat roda belakang melintasi batas bendera akhir dari segmen 1 stopwatch dihentikan dan dicatat kecepatan kendaraan yang melintas dalam 50 meter panjang lintasan pengukuran.

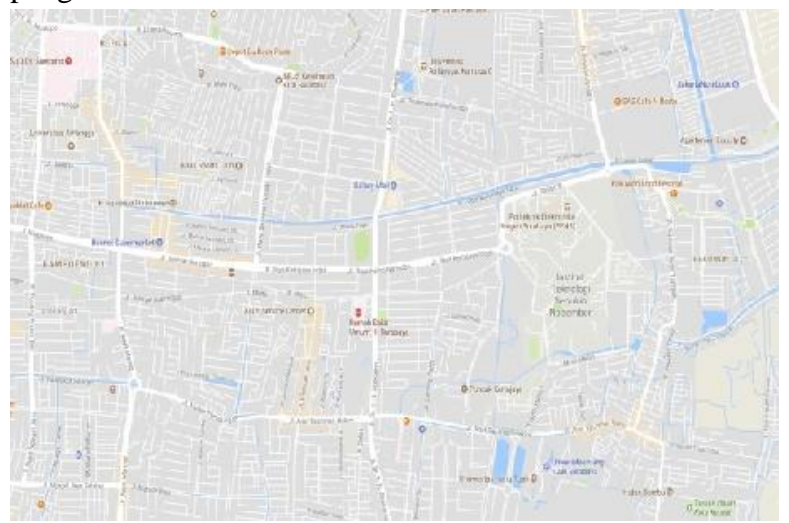

Gambar 2. Peta Jalan Lokasi Penelitian, Jalan Ir. H. Soekarno - Kertajaya Indah Surabaya 


\section{Hasil dan Pembahasan}

Hasil dari pengukuran untuk kecepatan kendaraan di segmen 1 dan segmen 2 diperlihatkan pada Tabel 1, dimana nilai pada Tabel 1 sudah merupakan hasil konversi dari satuan kecepatan kendaraan meter/detik menjadi $\mathrm{km} /$ jam[14].

Tabel 1. Data Kecepatan Kendaraan yang diukur Pada Segmen 1 Dan Segmen 2

\begin{tabular}{ccc}
$\begin{array}{c}\text { Waktu } \\
\text { penga- } \\
\text { matan }\end{array}$ & $\begin{array}{c}\text { Kecepatan } \\
\text { kendaraan segmen 1 } \\
(\mathrm{km} / \text { jam })\end{array}$ & $\begin{array}{c}\text { Kecepatan } \\
\text { kendaraan segmen } \\
2(\mathrm{~km} / \text { jam })\end{array}$ \\
\hline 1 & 54,2 & 37,4 \\
2 & 58,1 & 38,1 \\
3 & 47,3 & 42,6 \\
4 & 55,8 & 41,7 \\
5 & 42,7 & 37,5 \\
6 & 48,9 & 34,8 \\
7 & 53,7 & 32,5 \\
8 & 56,3 & 36,1 \\
9 & 49,1 & 30,5 \\
10 & 52,8 & 33,8 \\
11 & 44,6 & 37,9 \\
12 & 47,5 & 31,6 \\
\hline
\end{tabular}

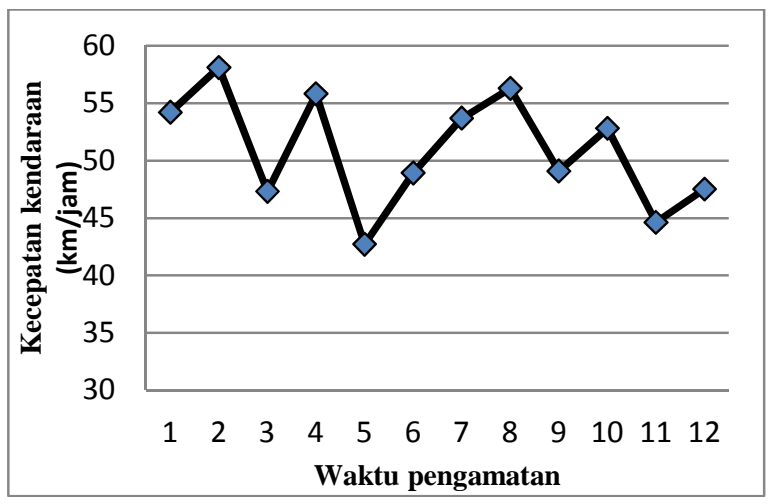

Gambar 3. Grafik kecepatan kendaraan pengamatan pada segmen 1

Untuk memudahkan pengamatan nilai maksimum dan rata-rata kecepatan yang akan diambil sebagai nilai masukan pada persamaan differernsial derajad 1, diberikan pada Gambar 2. Untuk segmen 1 dan Gambar 3, untuk pengamatan pada segmen 2 .

$$
S_{t}=S_{0}+C \cdot e^{-k \cdot t}
$$

Dengan menganggap bahwa pada saat kendaraan sudah berada pada garis pembatas penyebrangan atau zebra cross maka kecepatan dianggap nol $S_{0}=0$, dan persamaan (7) menjadi :

$S_{t}=C \cdot e^{-k \cdot t}$
Pada tabel 2. data statistik untuk kecepatan kendaraan pada segmen 1 memiliki kecepatan rata-rata sebesar 50,92 $\mathrm{km} / \mathrm{jam}$ dan pada segmen 2 memiliki kecepatan rata-rata sebesar 36,21 km/jam. Dengan menganggap bahwa segmen 1 sebagai segmen awal dari pergerakan perlambatan kendaraan dan dengan menganggap waktu awal sebagai nilai $\mathrm{t}=0$ maka dengan memasukkan nilai $50,92 \mathrm{~km} / \mathrm{jam}$ ke dalam persamaan perlambatan kecepatan diperoleh

$50,92=C \cdot e^{-k \cdot 0}$

Dengan menganggap bahwa nilai $e^{0}=1$, maka

$50,92=C .1$ atau $\mathrm{C}=50,92 \mathrm{~km} / \mathrm{jam}$

Maka persamaan matematis menjadi :

$S_{t}=50,92 \cdot e^{-k \cdot t}$

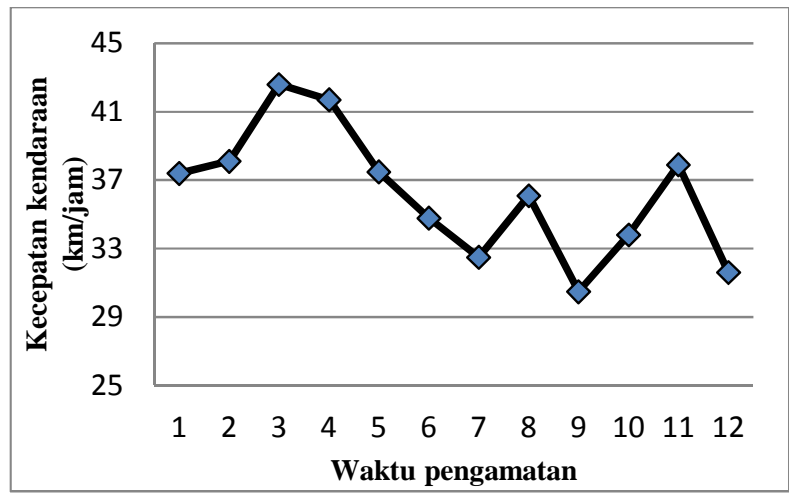

Gambar 4. Grafik Kecepatan Kendaraan Pengamatan Pada Segmen 2.

Tabel 2. Data statistik deskriptif untuk perhitungan segmen 1 dan segmen 2

\begin{tabular}{|c|c|c|c|}
\hline $\begin{array}{c}\text { Kecepatan } \\
\text { kendaraan } \\
\text { segmen } 1 \\
(\mathrm{~km} / \mathrm{jam})\end{array}$ & $\begin{array}{c}\text { Data } \\
\text { statistik }\end{array}$ & $\begin{array}{c}\text { Kecepatan } \\
\text { kendaraan } \\
\text { segmen } 2 \\
(\mathrm{~km} / \mathrm{jam})\end{array}$ & $\begin{array}{c}\text { Data } \\
\text { statistik }\end{array}$ \\
\hline $\begin{array}{c}\text { Mean } \\
\text { Standard }\end{array}$ & 50,9167 & Mean & 36,2083 \\
\hline Error & 1,4197 & Standard Error & 1,0868 \\
\hline $\begin{array}{l}\text { Median } \\
\text { Standard }\end{array}$ & 50,95 & $\begin{array}{c}\text { Median } \\
\text { Standard }\end{array}$ & 36,75 \\
\hline $\begin{array}{l}\text { Deviation } \\
\text { Sample }\end{array}$ & 4,9178 & Deviation & 3,7648 \\
\hline Variance & 24,1852 & Sample Variance & 14,1736 \\
\hline Minimum & 42,7 & Minimum & 30,5 \\
\hline Maximum & 58,1 & Maximum & 42,6 \\
\hline Sum & 611 & Sum & 434,5 \\
\hline Count & 12 & Count & 12 \\
\hline
\end{tabular}


Pada tabel 3 untuk segmen 2 dapat dilihat nilai rata-rata kecepatan kendaraan sebesar $36,21 \mathrm{~km} / \mathrm{jam}$. Untuk menghitung waktu tempuh pada saat melintas sepanjang garis pengamatan yaitu 50 meter adalah sebagai berikut: 50 meter dikonversi kedalam kilometer menjadi 0,05 kilometer, dan dengan menggunakan rumus 1 diperoleh waktu tempuh:

$$
\begin{aligned}
& 0,05=36,21 * \mathrm{t} \\
& \mathrm{t}=0,0014 \text { jam } \\
& \mathrm{t}=0,0014 * 3600 \text { detik } \\
& \mathrm{t}=4,97 \text { detik } \\
& S_{t}=50,92 \cdot e^{-k \cdot t} \\
& 36,21=50,92 \cdot e^{-k \cdot 4,97} \\
& 0,711=e^{-k \cdot 4,97} \\
& -k \cdot 4,97=\ln (0,711) \\
& -k \cdot 4,97=-0,341 \\
& k=\frac{0,341}{4,97}=0,0684
\end{aligned}
$$

Setelah diperoleh nilai konstanta $\mathrm{k}$, maka persamaan menjadi

$S_{t}=50,92 \cdot e^{-0,0684 . t}$

Pada saat mencapai garis zebra cross maka nilai St mencapai nol, tetapi dengan persamaan eksponen pada persamaan 11 nilai yang diambil adalah pada saat St mendekati $5 \mathrm{~km} / \mathrm{jam}$ dikarenakan pada kecepatan tersebut kendaraan dapat melakukan kontrol perlambatan kendaraan. Sehingga untuk waktu yang dibutuhkan pada saat diinginkan kendaraan memiliki kecepatan $5 \mathrm{~km} / \mathrm{jam}$ adalah:

$S_{t}=50,92 \cdot e^{-0,0684 . t}$ dengan memasukkan nilai $\mathrm{St}=5$ $\mathrm{km} / \mathrm{jam}$ maka diperoleh

$5=50,92 \cdot e^{-0,0684 \cdot t}$

$0,098=e^{-0,0684 . t}$

$-0,0684 \cdot t=\ln (0,098)$

$-0,0684 \cdot t=-2,32$

$t=\frac{2,32}{0,0684}=33,93$ detik

\section{SIMPULAN}

Dengan menggunakan persamaan differensial derajad 1 dapat dihasilkan suatu model matematis yang dapat menggambarkan situasi sesaat karakteristik kecepatan kendaraan yang ada pada suatu ruas jalan arteri khususnya di jalan Ir. H. Soekarno Surabaya.
Model persamaan yang dihasilkan untuk ruas jalan arteri tersebut adalah $S_{t}=50,92 \cdot e^{-0,0684 . t}$ dimana untuk setiap pertambahan waktu $\mathrm{t}$ sebesar 1 detik akan mengakibatkan nilai kecepatan St berubah sebesar 47,55 km/jam dari nilai awal sebesar $50,92 \mathrm{~km} / \mathrm{jam}$ saat $\mathrm{t}=0$ detik.

Model yang diperlihatkan disini masih membutuhkan penyempurnaan dengan melibatkan parameter yang lainnya seperti bentuk geometrik jalan, emosi dari pengendara kendaraan dan faktor cuaca seperti musim hujan.

\section{Daftar Pustaka}

[1] D. Delen, R. Sharda, and M. Bessonov, "Identifying significant predictors of injury severity in traffic accidents using a series of artificial neural networks," Accid. Anal. Prev., vol. 38, no. 3, pp. 434-444, May 2006.

[2] M. Skyving, H.-Y. Berg, and L. Laflamme, "A pattern analysis of traffic crashes fatal to older drivers," Accid. Anal. Prev., vol. 41, no. 2, pp. 253 258, Mar. 2009.

[3] C. Lee and M. Abdel-Aty, "Comprehensive analysis of vehicle-pedestrian crashes at intersections in Florida," Accid. Anal. Prev., vol. 37, no. 4, pp. 775786, Jul. 2005.

[4] S. Ma, Q. Li, M. Zhou, L. Duan, and D. Bishai, "Road Traffic Injury in China: A Review of National Data Sources," Traffic Inj. Prev., vol. 13, no. sup1, pp. 5763, Mar. 2012.

[5] M. Guerrieri, F. Corriere, G. Rizzo, B. Casto, and G. Scaccianoce, "Improving the Sustainability of Transportation: Environmental and Functional Benefits of Right Turn By-Pass Lanes at Roundabouts," Sustainability, vol. 7, no. 5, pp. 58385856, May 2015.

[6] D. Pojani and D. Stead, "Sustainable Urban Transport in the Developing World: Beyond Megacities," Sustainability, vol. 7, no. 6, pp. 77847805, Jun. 2015.

[7] M. Machsus, R. Basuki, and A. F. Mawardi, "Generalized Additive Models for Estimating Motorcycle Collisions on Collector Roads," Procedia Eng., vol. 125, pp. 411-416, Jan. 2015.

[8] Machsus, I. Prayogo, Chomaedhi, D. W. Hayati, and A. Utanaka, "Road safety analysis on Achmad Yani frontage road Surabaya," IOP Conf. Ser. Mater. Sci. Eng., vol. 267, no. 1, p. 12027, Nov. 2017.

[9] P. T. Savolainen, F. L. Mannering, D. Lord, and M. A. Quddus, "The statistical analysis of highway crash-injury severities: A review and assessment of 
methodological alternatives," Accid. Anal. Prev., vol. 43, no. 5, pp. 1666-1676, Sep. 2011.

[10] N. N. Sze and S. C. Wong, "Diagnostic analysis of the logistic model for pedestrian injury severity in traffic crashes," Accid. Anal. Prev., vol. 39, no. 6, pp. 1267-1278, Nov. 2007.

[11] M. Asbridge, J. R. Brubacher, and H. Chan, "Cell phone use and traffic crash risk: a culpability analysis," Int. J. Epidemiol., vol. 42, no. 1, pp. 259267, Feb. 2013.

[12] P. Cummings, F. P. Rivara, C. M. Olson, and K. M. Smith, "Changes in traffic crash mortality rates attributed to use of alcohol, or lack of a seat belt, air bag, motorcycle helmet, or bicycle helmet, United States, 1982-2001," Inj. Prev., vol. 12, no. 3, pp. 148-154, Jun. 2006.

[13] G. Brătucu, A. Madar, D. Boşcor, C. Băltescu, and N. Neacşu, "Road Safety Education in the Context of the Sustainable Development of Society: The Romanian Case," Sustainability, vol. 8, no. 3, p. 278, Mar. 2016.

[14] Direktorat Jenderal Bina Marga, "Manual Kapasitas Jalan Indonesia," Jakarta, 1997. 
